\title{
Is intrathecal anti-CD20 an option to target compartmentalized CNS inflammation in progressive MS?
}

\section{OPEN}

Martin S. Weber, MD

Correspondence to Dr. Weber:

martin.weber@med.unigoettingen.de

Neurol Neuroimmunol Neuroinflam

2015;2:e84; doi: 10.1212/ NXI.0000000000000084

See article
$\mathrm{B}$ cells have gained enormous attention in the treatment of multiple sclerosis (MS). While our earlier pathogenic understanding of its cause primarily focused on B cell-derived plasma cells producing self-reactive antibodies, more recent findings support the theory that B cells themselves substantially contribute to MS pathogenesis. This conceptual change was primarily triggered by the empirical observation that anti-CD20-mediated B-cell depletion is effective in the treatment of relapsing-remitting MS (RRMS). Clearly exceeding the initial expectations, IV rituximab led to a rapid and lasting halt in the formation of new CNS lesions in patients with RRMS. ${ }^{1}$ Its further humanized successor ocrelizumab, ${ }^{2}$ as well as the human anti-CD20 antibody ofatumumab, ${ }^{3}$ confirmed these encouraging findings. The clinical efficacy of anti-CD20 provided greater appreciation of the fact that antigen-specific $\mathrm{B}$ cells are important antigenpresenting cells (APCs), ${ }^{4,5}$ most likely due to their unique capability to directly bind larger conformational antigens at very low concentrations via their B-cell receptor. Furthermore, B cells could be identified as a major source of proinflammatory cytokines, ${ }^{6}$ activating other APCs and fostering development of encephalitogenic $\mathrm{T}$ cells, jointly consolidating the concept that in RRMS, B cells exert distinctive pathogenic properties that can be targeted by systemic anti-CD20 treatment.

Emerging evidence suggests that throughout the chronic course of MS, pathogenic B-cell function gradually shifts from the periphery into the inflamed CNS. This notion is supported by the observation of B-cell follicle-like lymphatic tissue in the meninges of a proportion of patients with secondary progressive MS.7 Development of such ectopic structures is generally believed to indicate reproduction and differentiation of pathogenic lymphocytes within the target organ itself; this may partially explain why in later stages of MS clinical progression decreasingly correlates with MRI-detectable CNS infiltration while histopathology remains inflammatory. ${ }^{8}$ In this setting of compartmentalized CNS inflammation, systemically applied MS agents, in particular molecularly large monoclonal antibodies, may lose their effectiveness. Supporting this notion, only $0.1 \%$ of systemically infused anti-CD20 can be found within the CSF, ${ }^{9}$ raising the concern that parenchymal $\mathrm{B}$ cells as well as meningeal $\mathrm{B}$ cells and/or B-cell follicles cannot be reached and depleted by systemic anti-CD20. Accordingly, one strategy currently being explored to eradicate CNS-established B cells more efficiently is intrathecal (IT) administration of anti-CD20 in patients with progressive MS.

In this issue of Neurology ${ }^{\circledR}$ Neuroimmunology \& Neuroinflammation, Svenningsson et al. ${ }^{10}$ report their 1 -year findings from a phase $1 \mathrm{~b}$ study in which they tested IT injection of rituximab in 10 patients with progressive MS. Rituximab was provided via an Ommaya reservoir connected to a ventricular catheter. In the first 3 patients the dose was titrated, with daily applications of $1 \mathrm{mg}, 2.5 \mathrm{mg}, 5 \mathrm{mg}, 10 \mathrm{mg}$, and finally $25 \mathrm{mg}$ rituximab; lymphocyte subpopulations were monitored daily during this dose escalation period. All 10 patients thereafter received 3 weekly IT injections of $25 \mathrm{mg}$ rituximab, and peripheral as well as CSF lymphocyte subpopulations were assessed every 2-3 months. As a first finding, the authors report a substantial decline of peripheral B cells, even after the initial application of $1 \mathrm{mg}$ IT rituximab. Following the second dose of $2.5 \mathrm{mg}$, B lymphocytes became undetectable in the blood, and the full dose of $3 \times 25 \mathrm{mg} /$ week resulted in complete depletion of peripheral lymphocytes lasting for 2-3 months. In 2 patients with elevated baseline CSF lymphocyte counts, B-cell frequency rapidly declined upon IT administration of rituximab, whereas in all other patients possible changes remained undetectable due to very low initial CSF lymphocyte counts.

Although the primary outcome of this study, the safety and tolerability of IT anti-CD20 in progressive MS, will be reported upon study completion, we can draw a few important conclusions from these 1-year data. First, up to this point, IT application of rituximab seems to be well-tolerated. Second, the doses

From the Institute of Neuropathology and Department of Neurology, University Medical Centre, Göttingen, Germany.

Funding information and disclosures are provided at the end of the article. Go to Neurology.org/nn for full disclosure forms. The Article Processing Charge for this editorial was waived at the discretion of the Editor.

This is an open access article distributed under the terms of the Creative Commons Attribution-Noncommercial No Derivative 3.0 License, which permits downloading and sharing the work provided it is properly cited. The work cannot be changed in any way or used commercially. 
used systemically to date are likely substantially higher than required for rituximab's immunologic effect. This notion is in line with ongoing clinical trials evaluating markedly lower doses of anti-CD20 systemically. Third, using this route of administration, the CNS cannot be targeted selectively, which could have been desirable to deplete pathogenic B cells while avoiding the systemic side effects of pan-B cell depletion. This key observation likely refers to the earlier finding that injected IT anti-CD20 has a very short half-life in the CSF and accumulates within the serum. ${ }^{9}$ Probably the most important and related limitation of this study is that it remains uncertain whether IT administration is truly capable of depleting B cells within the CNS or whether the drop in CSF B-cell counts is a consequence of a systemic effect. In an attempt to address this question, a recent experimental study compared IT anti-CD20 to its systemic application and observed that IT administration of anti-CD20 was indeed superior in depleting meningeal $\mathrm{B}$ cells in established CNS autoimmune disease. ${ }^{11}$ In conclusion and in this context, the study conducted by Svenningsson et al. is an important contribution to pioneering the use of IT anti-CD20 in the treatment of progressive MS, fueling hopes that a facilitated elimination of CNS B cells may translate into clinical benefit.

\section{STUDY FUNDING}

No targeted funding reported.

\section{DISCLOSURE}

M.S. Weber is serving as an editor for PLoS One; received travel funding and/or speaker honoraria from Biogen-Idec, Merck Serono, Novartis, Roche, and Bayer; and receives research support from the National Multiple Sclerosis Society, the Deutsche Forschungsgemeinschaft, Novartis, TEVA, BiogenIdec, Roche, and the ProFutura Programme of the Universitätsmedizin Göttingen. Go to Neurology.org/nn for full disclosure forms.

\section{REFERENCES}

1. Hauser SL, Waubant E, Arnold DL, et al; HERMES Trial Group. B-cell depletion with rituximab in relapsingremitting multiple sclerosis. N Engl J Med 2008;358: 676-688.

2. Kappos L, Li D, Calabresi PA, et al. Ocrelizumab in relapsing-remitting multiple sclerosis: a phase 2, randomised, placebo-controlled, multicentre trial. Lancet 2011; 378:1779-1787.

3. Sorensen PS, Lisby S, Grove R, et al. Safety and efficacy of ofatumumab in relapsing-remitting multiple sclerosis: a phase 2 study. Neurology 2014;82:573-581.

4. Weber MS, Prod'homme T, Patarroyo JC, et al. B-cell activation influences $\mathrm{T}$-cell polarization and outcome of anti-CD20 B-cell depletion in central nervous system autoimmunity. Ann Neurol 2010;68:369-383.

5. Molnarfi N, Schulze-Topphoff U, Weber MS, et al. MHC class II-dependent B cell APC function is required for induction of CNS autoimmunity independent of myelin-specific antibodies. J Exp Med 2013;210:2921-2937.

6. Bar-Or A, Fawaz L, Fan B, et al. Abnormal B-cell cytokine responses a trigger of T-cell-mediated disease in MS? Ann Neurol 2010;67:452-461.

7. Magliozzi R, Howell O, Vora A, et al. Meningeal B-cell follicles in secondary progressive multiple sclerosis associate with early onset of disease and severe cortical pathology. Brain 2007;130:1089-1104.

8. Lassmann H. New concepts on progressive multiple sclerosis. Curr Neurol Neurosci Rep 2007;7:239-244.

9. Rubenstein JL, Fridlyand J, Abrey L, et al. Phase I study of intraventricular administration of rituximab in patients with recurrent CNS and intraocular lymphoma. J Clin Oncol 2007;25:1350-1356.

10. Svenningsson A, Bergman J, Dring A, et al. Rapid depletion of B lymphocytes by ultra-low-dose rituximab delivered intrathecally. Neurol Neuroimmunol Neuroinflamm 2015;2:e79; doi: 10.1212/NXI.0000000000000079.

11. Lehmann-Horn K, Kinzel S, Feldmann L, et al. Intrathecal anti-CD20 efficiently depletes meningeal $\mathrm{B}$ cells in CNS autoimmunity. Ann Clini Transl Neurol 2014;1: 490-496. 


\title{
Neurology $^{\odot}$ \\ Neuroimmunology \& Neuroinflammation
}

\author{
Is intrathecal anti-CD20 an option to target compartmentalized CNS inflammation in \\ progressive MS? \\ Martin S. Weber \\ Neurol Neuroimmunol Neuroinflamm 2015;2; \\ DOI 10.1212/NXI.0000000000000084
}

This information is current as of March 12, 2015

Updated Information \&
Services

References

Subspecialty Collections

Permissions \& Licensing

Reprints including high resolution figures, can be found at:

http://nn.neurology.org/content/2/2/e84.full.html

This article cites 11 articles, 2 of which you can access for free at: http://nn.neurology.org/content/2/2/e84.full.html\#\#ref-list-1

This article, along with others on similar topics, appears in the following collection(s):

Autoimmune diseases

http://nn.neurology.org//cgi/collection/autoimmune_diseases

\section{Class IV}

http://nn.neurology.org//cgi/collection/class_iv

Clinical trials Observational study (Cohort, Case control)

http://nn.neurology.org//cgi/collection/clinical_trials_observational_stu dy_cohort_case_control

Multiple sclerosis

http://nn.neurology.org//cgi/collection/multiple_sclerosis

Information about reproducing this article in parts (figures,tables) or in its entirety can be found online at:

http://nn.neurology.org/misc/about.xhtml\#permissions

Information about ordering reprints can be found online:

http://nn.neurology.org/misc/addir.xhtml\#reprintsus

Neurol Neuroimmunol Neuroinflamm is an official journal of the American Academy of Neurology.

Published since April 2014, it is an open-access, online-only, continuous publication journal. Copyright $\odot$ 2015 American Academy of Neurology. All rights reserved. Online ISSN: 2332-7812.

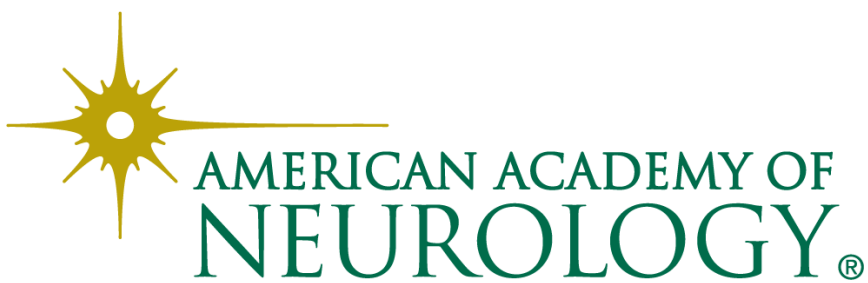

